\title{
THE CODA MIRROR V2
}

\author{
TOBIAS SCHEER ${ }^{\mathrm{a}}$ - MARKÉTA ZIKOVÁ ${ }^{\mathrm{b}}$ \\ ${ }^{a}$ Université de Nice-Sophia Antipolis, CNRS 6039 \\ Faculté des Lettres; Laboratoire BCL \\ 98, Bd Herriot; B.P. 3209; F-06204 Nice, France \\ scheer@unice.fr \\ ${ }^{\mathrm{b}}$ Masarykova Univerzita v Brně \\ Arna Nováka 1 \\ 60200 Brno \\ Czech Republic \\ zikova@phil.muni.cz
}

\begin{abstract}
This article further develops Coda Mirror theory (Ségéral-Scheer 2001a): its shortcomings are identified (overgeneration: the super-weak position predicted has no empirical echo, and the four-way parametric situation predicted in domain-final position is confronted with only two attested configurations), and a solution is proposed by dispensing with the equal-rightedness of government and licensing. Government over licensing is the principle proposed: no constituent can simultaneously be the target of both lateral forces, and if both could in principle apply, government is given precedence. A welcome by-product of this move is a new definition of open vs. closed syllables that makes sense: vowels in the former, but not in the latter, are licensed.
\end{abstract}

Keywords: Coda Mirror, lenition, extrasyllabicity, Government Phonology, closed/open syllable

\section{Introduction}

The Coda Mirror is a theory of lenition and fortition that is couched in the syllabic environment CVCV (or strict CV). ${ }^{1}$ It was laid out in Ségéral-Scheer (2001a), ${ }^{2}$ and has known various implementations and

${ }^{1}$ CVCV was initiated by Lowenstamm (1996) and is developed, among others, by Szigetvári (2001); Cyran (2003); Scheer (1998c; 2004a); Passino (2008); Ziková (2008); Rowicka (1999).

2 Ségéral-Scheer (2001a) is a slightly more evolved French version of the original English manuscript Ségéral-Scheer (1999), which is available online. 
applications. ${ }^{3}$ Below we develop the Coda Mirror further by amending its mechanics in one central point: government and licensing are not equal-righted. The motivation for this move comes from the wordfinal (or rather: domain-final, see Kaye 1995) situation, i.e., where nonphonological factors come into play. Shaping linguistic theory according to interface requirements is of course a very minimalist thing to do. ${ }^{4}$

\section{The Coda Mirror as it stands}

The central idea of the Coda Mirror is that positional strength of consonants depends on the distribution of empty nuclei. The five relevant positions cluster into two disjunctions according to their behaviour, plus the intervocalic position $\mathrm{V}_{-} \mathrm{V}$ : the coda $\_\{\#, \mathrm{C}\}$ and its mirror, the Strong Position $\{\#, C\}$ _ . As may be seen under (1) below, the two disjunctions are reduced by the Coda Mirror so that consonants in coda position occur before empty nuclei $(\emptyset)$, while consonants in the Strong Position are found after empty nuclei (and intervocalic consonants are not adjacent to any empty nucleus).

(1) The five positions and their interpretation in the Coda Mirror

\begin{tabular}{|c|c|c|c|c|c|}
\hline \multicolumn{2}{|c|}{ Position } & \multicolumn{2}{|l|}{ Usual name } & \multirow{3}{*}{$\emptyset_{-}$} & \multirow{6}{*}{ weak positions } \\
\hline (a) & $\# \_\mathrm{V}$ & word-initial & Strong & & \\
\hline (b) & VC._ V & post-coda & Position & & \\
\hline (c) & $\mathrm{V}$ _. CV & internal coda & & & \\
\hline (d) & $\mathrm{V}$ —\# & final coda & Coda & - & \\
\hline (e) & $\mathrm{V}-\mathrm{V}$ & intervocalic & $\mathrm{V} \_\mathrm{V}$ & no adjacent $\emptyset$ & \\
\hline
\end{tabular}

The Coda Mirror builds on the Mirror effect: it can hardly be by accident that the coda and its mirror, the Strong Position, are exactly symmetric not only as far as their structural description is concerned $\left(—\{\#, \mathrm{C}\}\right.$ vs. $\left.\{\#, \mathrm{C}\} \_\right)$, but also regarding their effect: coda consonants

3 Among others, the following may be quoted: Szigetvári (1999; 2008); Cyran (2003; 2008); Seigneur-Froli (2003; 2006); Ségéral-Scheer (2001b; 2005; 2008a;b), Scheer (2004a, §§110, 556; 2004b); Marotta (2008); Kijak (2005); Csides (2000; 2007); Passino (2008).

${ }^{4}$ This article is a piece of Scheer (forthcoming), where a more elaborated version appears.

Acta Linguistica Hungarica 57, 2010 
are weak, while coda mirror consonants are strong. The reduction of both disjunctions, an insuperable obstacle in a traditional syllabic environment, produces the same symmetry (_ $\emptyset$ vs. $\emptyset_{-}$). The question why the former, rather than the latter is weak (and the latter, rather than the former strong) is answered by the lateral relations government and licensing that make the architecture of syllable structure in CVCV (which is thus built on lateral dependency-type relations, rather than on trees).

Government spoils the segmental expression of its target, while licensing provides support. Each nucleus that is a good lateral actor (i.e., that can dispense lateral relations) can govern and license, and will always do so (a nucleus cannot "decide" not to govern or not to license). Empty nuclei require government from the following nucleus, which is therefore unable to govern its own onset. This is the reason why empty nuclei introduce a disruption of the intervocalic equilibrium. Table (2) below shows the effect of empty nuclei on following consonants, which stand in Strong Position (target consonants are underscored). Following Lowenstamm (1999), the beginning of the word is represented by an empty CV unit (see e.g., Ségéral-Scheer 2008b for discussion).

(2) Consonants in Strong Position: ungoverned but licensed
(a) initial consonant \#-
(b) post-coda consonant C.
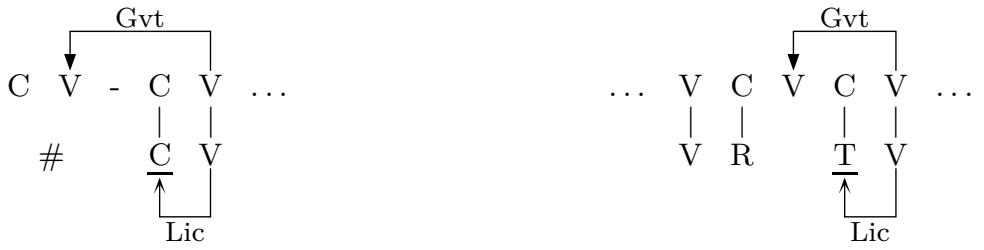

The nucleus following word-initial and post-coda consonants is called to govern its preceding peer, which is empty. It cannot govern its own onset for that reason. At the same time, the nucleus in question has no specific licensing duties and therefore licenses its own onset. A consonant in strong position is thus licensed but ungoverned.

Table (3) below shows the situation of the three remaining positions.

Consonants in the coda disjunction $(3 \mathrm{a}, \mathrm{b})$ occur before an empty nucleus; they are both ungoverned and unlicensed for that reason: empty nuclei are laterally disabled. On the other hand, intervocalic consonants are not adjacent to any empty nucleus. They are therefore governed and licensed: their nucleus is contentful (and hence a good lateral actor), but unlike under (2), it has no governing duties. 
(3) Consonants in codas: ungoverned and unlicensed Intervocalic consonants: both governed and licensed
(a) internal coda _. C
(b) final coda _ \#
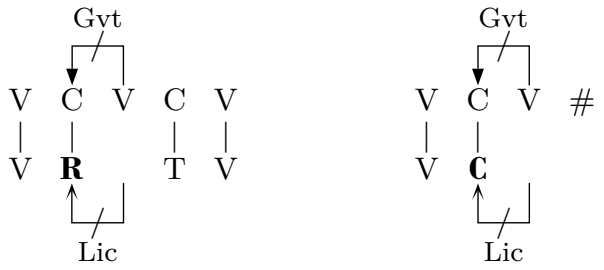
(c) intervoc. $\mathrm{V}-\mathrm{V}$

In sum, the two lateral relations define the five positions as follows.

(4)

\begin{tabular}{cccc}
\hline Licensing & Government & Position & $\begin{array}{c}\text { Segmental health } \\
\text { according to predictions }\end{array}$ \\
\hline \multirow{2}{*}{+} & - & Coda Mirror & splendid \\
& + & $\mathrm{V}-\mathrm{V}$ & unfavourable \\
- & - & Coda & unfavourable \\
& + & impossible & - \\
\hline
\end{tabular}

The fourth logical possibility, i.e., where a consonant is governed but not licensed, was held to be impossible by Ségéral-Scheer (2001a). It may be called the nightmare position since consonants will be spoiled (by government) and in addition unsupported (by licensing). The nightmare position will play a prominent role below.

\section{FEN: the parametric system of Scheer (2004a) overgenerates}

\subsection{Four logical possibilities}

Table (5) below reproduces the four-way parametric space that is generated in Scheer (2004a, §545), i.e., on the assumption that government and licensing apply independently (their source is the Final Empty Nucleus, FEN).

That this system overgenerates was already made explicit in Scheer (2004a, §543), and is also pointed out in Cyran's (2006, 534ff) review of the book. Cyran goes through the detail of the predicted configurations that do not appear to correspond to any empirical record. 
(5) The word-final situation: four-way parametric system of Scheer (2004a, §545)

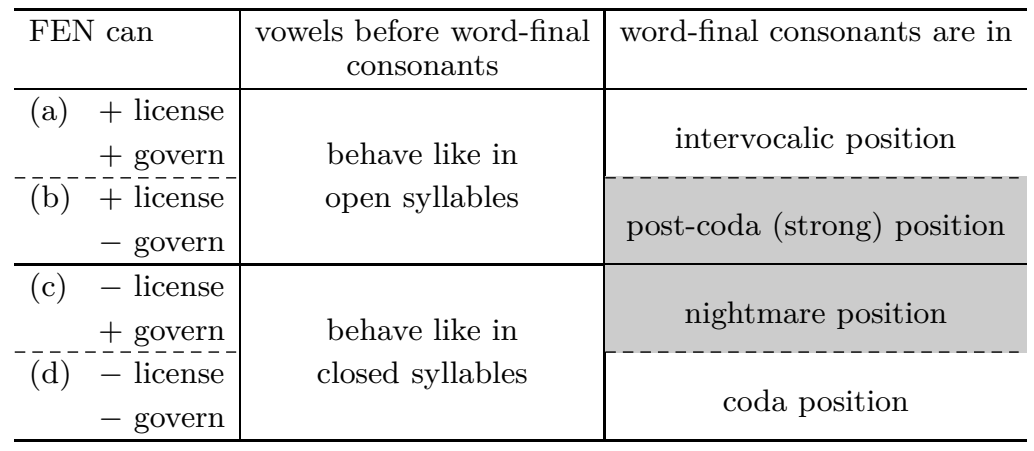

It was already mentioned that the two predicted situations that stand without empirical echo are the two grey-shaded cells under (5). An analysis of this picture shows that it is government, not licensing, that makes the system overgenerate.

There are two well-known loci of variation at the right edge of the word: long vowels before word-final consonants may or may not be subject to closed syllable restrictions (closed syllable shortening, open syllable lengthening), and word-final consonants may or may not behave as codas. Both are controlled by the same parameter; i.e., extrasyllabicity in traditional terms, licensing in the Coda Mirror.

Let us first look at consonants. In languages where FEN can license, word-final consonants do not behave like codas (i.e., they are extrasyllabic) because they are licensed - unlike coda consonants, which are not. On the other hand, word-final consonants behave like true codas in case FEN are unable to license Scheer (2004a, §542). Unfortunately, the binary choice that is produced by licensing alone is further expanded when government comes into play: FEN that are able to license may or may not be able to govern (see $(5 \mathrm{a}, \mathrm{b})$ ), just as FEN that cannot license (see $(5 \mathrm{c}, \mathrm{d}))$. According to the standards of the Coda Mirror v1, licensed wordfinal consonants are intervocalic when also governed (5a), but stand in strong position when remaining ungoverned (5b). On the other hand, unlicensed word-final consonants are only true codas when also ungoverned (5d). Otherwise, they are in the weakest possible situation, the nightmare position (5c).

The length of vowels before word-final consonants is also controlled by licensing. This follows from the definition of long vowels, whose complement needs to be licensed. Long vowels that alternate in length are 
left-headed. Hence their complement nucleus $\left(\mathrm{V}_{2}\right.$ in $\left.\mathrm{V}_{1} \mathrm{~V}_{2} \mathrm{C} \emptyset \mathrm{CV}\right)$ fails to be licensed in closed syllables: the following nucleus is empty and governed (Scheer 2004a, §§230, 532). Therefore in languages such as Icelandic, where closed syllable shortening applies word-internally, but not in word-final syllables (/VVRTV/ does, but /VVC\#/ does not shorten), $\mathrm{V}_{2}$ in $\mathrm{V}_{1} \mathrm{~V}_{2} \mathrm{C} \emptyset$ \# must receive licensing. The only possible source is the FEN. In other words, in extrasyllabic languages where the final consonant does not count for syllabic matters, FEN are able to dispense licensing. By contrast in languages where closed syllable shortening affects internal and final syllables alike, FEN are unable to license.

Although the literature does not really address the question whether vocalic and consonantal effects of extrasyllabicity always go hand in hand, the prediction that the licensing power of FEN decides for both appears to meet the empirical record: "extrasyllabic once, extrasyllabic forever" (see Scheer 2004a, §§364, 551). That is, there are no "half-extrasyllabic" languages: word-final consonants cannot be extrasyllabic just for effects that concern their own body (but not for those that affect preceding vowels), and the reverse pattern is also excluded.

\subsection{The nightmare position is unwarranted}

The nightmare position, however, does not appear to have any empirical response: there are no super-weak consonants (which on top occur only in word-final position). Also, it falls foul of another empirical generalization (Ségéral-Scheer 2008a; Scheer 2004a, §536). The variable item of the two disjunctions is always located at the edge: either both internal and final coda consonants behave like codas ( $\mathrm{C \#}$ is not extrasyllabic), or only internal coda consonants behave like codas (while $\mathrm{C} \#$ behave as noncodas, i.e., are extrasyllabic in traditional terms); the reverse pattern, however, where word-final consonants behave like codas but internal coda consonants do not, does not exist (e.g., $l$-vocalization affects either both pre-consonantal and word-final codas like in Brazilian Portuguese, or only pre-consonantal codas like in (Old) French). The same is true for the Strong Position: either both word-initial and post-coda consonants are strong like in Romance, or only the internal member of the disjunction, i.e., post-coda consonants, is strong, while word-initial consonants behave like intervocalic consonants; this pattern is found in Greek (Seigneur-Froli $2003 ; 2006)$. The reverse pattern where word-initial consonants are strong, but post-coda consonants are not, is not on record.

Acta Linguistica Hungarica 57, 2010 
It also follows from this generalization that edge consonants can only deviate from the internal member of their disjunction in the opposite direction of strength: codas are weak, and word-final consonants may be non-weak (i.e., extrasyllabic); coda mirror consonants are strong, and word-initial consonants may be non-strong (i.e., intervocalic). Nightmare consonants, however, would deviate from the strength pattern of their disjunction by being weaker than codas. This violates the generalization.

\subsection{Only two patterns have an empirical echo}

In sum, only two cases out of four seem to make sense: those which have concordant values for government and licensing. Either word-final consonants are both governed and licensed as under (5a), which makes them intervocalic and hence extrasyllabic, or they are neither governed nor licensed as under (5d), in which case they are true codas, i.e., nonextrasyllabic.

If the arbitral award of the empirical echo is taken seriously, what needs to be done in order to eliminate overgeneration is to get rid of (5b) and $(5 \mathrm{c})$. Translated into lateral terms, the rationale is clear: government and licensing must not be independently parameterised. That is, either FEN can dispense both, or neither.

Note that the reduction from four to two options is neutral with respect to the second locus of variation: since the length of vowels in final syllables depends only on licensing, all that is needed in order to cover the pattern is a binary distinction between FEN that can and FEN that cannot license. The reduced system offers this contrast: table (5) shrinks to just (5a) and (5d), which cover both the consonantal and the vocalic variation.

Finally, as before, consonantal and vocalic effects of extrasyllabicity are covered by the same parameter, i.e., the (in )ability of FEN to license.

It thus seems that the reduction of the parametric possibilities to just those which have concordant values for government and licensing allows for a better fit with the empirical situation. While this is certainly an encouraging result, more needs to be done: the following section shows that the system continues to produce the nightmare situation $(5 \mathrm{c})$. 


\subsection{The nightmare position is a nightmare for the theory: it also occurs word-internally}

Even though the shrunk parametric system of FEN does not produce the nightmare position (5c) anymore, this position continues to occur in two other circumstances.

In languages where FEN can license, vowels in final closed syllables are long (Icelandic is a case in point, see Scheer 2004a, §§533, 544 for data and literature). In such a language word-final consonants should also be extrasyllabic since they will be licensed by the FEN. This, however, is only true when they follow a short vowel: they fail to be licensed (while still being governed) when preceded by a long vowel because the FEN is called to license the preceding nucleus. The relevant situation is depicted under (6) below.

(6) Extrasyllabic languages (i.e., where FEN can license and govern)

(a) $\mathrm{C \#}$ following a lexically short vowel: intervocalic position

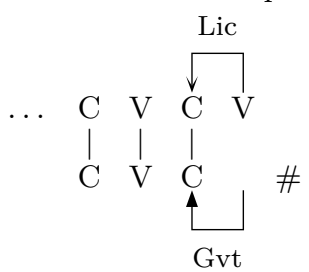

(b) $\mathrm{C} \#$ following a lexically long vowel: nightmare position

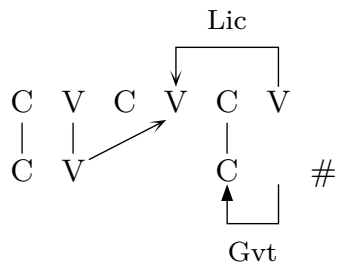

Word-final consonants thus experience different conditions according to whether they are preceded by an underlyingly short or long vowel. In the former case (6a), they are intervocalic in terms of the Coda Mirror v1 (both licensed and governed), while they face nightmare conditions in the latter (governed but unlicensed, (6b)).

This kind of variable consonantal strength according to whether the preceding vowel is long or short hardly meets any empirical echo. We do not know whether the relative strength of word-final consonants can be controlled in Icelandic (or in other languages where closed syllable shortening occurs only in internal syllables). If it turns out to be identical for (6a) and (6b), the scenario of (6) is not refuted since the results of lenition in the intervocalic and the nightmare position could coincidentally be the same (just as intervocalic and coda consonants behave alike in some languages). Hence it will be difficult to falsify the prediction that is made by 
(6). Only a language that indeed attests different reactions of word-final consonants under (6a) and (6b) could provide positive evidence.

In any event, then, it is safe to say that the existence of the nightmare position is certainly not something that a theory can be proud of.

The second instance of the nightmare position is the word-internal equivalent of $(6 \mathrm{~b})$, i.e., where a long vowel precedes an intervocalic consonant (/VVCV/). This configuration is identical to (6b), except that the consonant in question is followed by a contentful nucleus, which is called to license the second nucleus of the preceding long vowel as before. The consonant enclosed will therefore be unlicensed but governed, hence super-weak.

It may be doubted that empirical response is waiting out there, whether in internal or in final position. ${ }^{5}$ We therefore consider the nightmare position to be a nightmare for the theory: it needs to be done away with.

\section{Coda Mirror v2: government and licensing must not be equal-righted}

\subsection{Unitary abilities of FEN cannot be the only answer}

The preceding discussion has identified the overgeneration that the parametric system of FEN has produced in Scheer (2004a), as well as its origin, the independent application of government and licensing. That is, overgeneration at the right edge of the word can be eliminated if the lateral abilities of FEN reduce to an on/off setting: either FEN are lateral actors and can both govern and license, or they are not, in which case they can dispense neither lateral force. This move prevents the system from generating word-final consonants in strong and in nightmare position.

While this offers a correct description of extrasyllabicity (including its effects on vowels), we have seen in section 3.4 that the Coda Mirror as it stands produces the nightmare position also word-internally. This

${ }^{5}$ Balogné Bérces $(2005,144 \mathrm{ff})$ mentions data from English that seem to show that if anything, word-internal consonants after short vowels are weaker than after long vowels, i.e., the reverse of the situation predicted by (6). That is, in some dialects tapping appears to occur after short vowels as in latter, but not after long vowels as in later. 
is motivation enough for engaging into a revision of the lateral network, that is of the Coda Mirror as such. Following Cyran (2006), the guiding idea will be that government and licensing are not equal-righted. We will see that a side-effect of the revised system also offers a better definition of the opposition between open and closed syllables.

\subsection{Government over licensing}

In his review of Scheer (2004a), Cyran $(2006,534)$ recommends to formalize the interaction between government and licensing. The revision of the phonological engine of CVCV that is proposed below follows this advice. The challenge is to modify the rule of the game so as to get rid of the nightmare position while not losing any of the generalisations regarding syllable structure and the Coda Mirror. Touching any piece of the puzzle impacts the mechanics elsewhere. This is of course warranted, but severely restricts the room for modifications.

The guiding idea is that government and licensing do not act independently of one another; rather, they obey a natural hierarchy that determines their behaviour when they could in principle apply simultaneously. ${ }^{6}$

(7) Government over licensing

No constituent can be governed and licensed at the same time. In case a constituent can potentially be subject to both lateral forces, it will be governed.

The following sections discuss the impact of this principle first on the Coda Mirror itself (the general word-internal situation), then on the parametric situation at the right edge (section 5).

\subsection{Consequences for the Coda Mirror: intervocalic consonants}

(7) impacts most directly the identity of intervocalic consonants: while they were both governed and licensed before, they are now only governed.

${ }^{6}$ In a different environment, Balogné Bérces $(2001,53)$ has also argued that "[a] consonant [...]cannot be simultaneously governed and licensed by the same vowel." In case a vowel could in principle dispense both lateral forces, the conflict is resolved according to stress on her analysis: stressed vowels (in English) prefer to license, while unstressed vowels rather govern their onset. 
This move also addresses a critique that is sometimes levelled against the Coda Mirror (among others by Cyran 2006, 530ff, 537): how could the reaction of an onset be calculated if its melodic expression is simultaneously inhibited and enhanced? Intuitively, opposite forces cancel each other out. The Coda Mirror has always been explicitly agnostic regarding the interpretation of simultaneously governed and licensed constituents. The only thing that was important was the ability of the theory to formally distinguish the two weak positions, intervocalic and the coda ("two ways of being weak", cf. Scheer 2004a, §131; Szigetvári 2008), while making sure that both of them are weaker than the Strong Position.

As a matter of fact, thus, the relative strength of both weak positions remained an open question (see Scheer 2004a, §§130f). On the assumption of (7), the theory now makes a clear statement: consonants are weaker in intervocalic than in coda position since the former are spoiled (and only spoiled), while the latter do not experience any lateral influence. One could say that they appear "naked" on the surface, i.e., in the positional conditions that are produced by the absence of phonological computation. Figures $(8 \mathrm{a}, \mathrm{b})$ below recall the situation of coda consonants, which is unchanged, while (8c) shows intervocalic consonants when (7) is applied.

(8) Coda Mirror v2

Consonants in codas: ungoverned and unlicensed Intervocalic consonants: governed but unlicensed

(a) internal coda _-. C

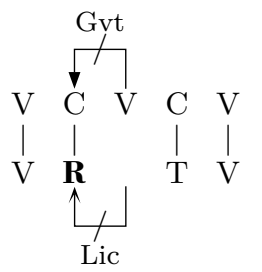

(b) final coda _ \#

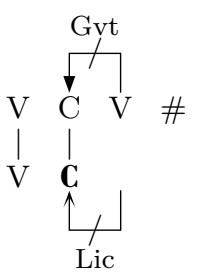

(c) intervoc. $\mathrm{V}-\mathrm{V}$

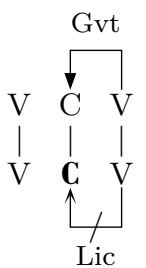

The confrontation with the empirical record must show whether it is true that intervocalic consonants are weaker than consonants in coda position. A hint that this could be correct is the implicational relationship that appears to govern spirantisation patterns across languages: spirantisation in codas only seems to occur if it is also observed intervocalically; on the other hand, in many systems intervocalic consonants spirantise without spirantisation affecting codas. Hence the attack of spirantisation appears to first consider the weakest targets - intervocalic consonants - , and may then optionally extend to more solid codas (see Szigetvári 2008 on this issue). 
The general conditions that consonants experience when (7) is applied appears under (9) below. Note that the only situation that is modified with respect to the Coda Mirror v1 is the intervocalic position: the definition of the Strong Position and the coda is as before.

(9) Coda Mirror v2

\begin{tabular}{|c|c|c|c|}
\hline \multirow{4}{*}{$\begin{array}{l}\text { (a) } \\
\text { (b) } \\
\text { (c) }\end{array}$} & \multicolumn{2}{|l|}{ position } & \multirow{2}{*}{$\frac{\text { definition in terms of lateral relations }}{\text { licensed but ungoverned }}$} \\
\hline & Strong Position & $\{\#, C\}-$ & \\
\hline & coda & $-\{\#, C\}$ & unlicensed and ungoverned \\
\hline & intervocalic & $\mathrm{V} \_\mathrm{V}$ & governed (but unlicensed) \\
\hline
\end{tabular}

The fourth logical possibility, i.e., a constituent that is both governed and licensed, is ruled out by (7). Also note that the configuration "governed but unlicensed" characterised the nightmare position before, but now describes regular intervocalic onsets. Therefore the system is unable to produce a situation where a consonant is weaker than both codas and intervocalic onsets. That is, (7) kills two birds with one stone: the equal-rightedness of government and licensing is done away with, and the nightmare position is eliminated.

Section $\mathbf{4 . 4}$ shows that the nightmare position is really absent from the plot, also when it comes to the representation of vowel length.

\subsection{Intervocalic relations}

\subsubsection{Long vowels}

The revised lateral identity of intervocalic onsets has also consequences for internuclear relations. In order to see that, consider the ground rules under (10) below. Note that they have not varied since Scheer (2004a) and the Coda Mirror v1, except for (10cii), which is a consequence of (7).

(10) Origin and application of lateral relations

(a) Nuclei exhaust their lateral potential: nuclei which are enabled to govern do govern, nuclei which are enabled to license do license (Scheer 2004a, §148).

(b) By default, nuclei target their own onset, i.e., "choose" the shortest move.

(c) They target other nuclei in two situations:

(i) when they are called to either govern or license a preceding empty nucleus;

(ii) when they govern their onset and hence cannot license it simultaneously. 
In a language where the initial CV marks the beginning of the word, the Strong Position is thus unchanged as under (11) below.

(11) Consonants in Strong Position: ungoverned but licensed

(a) initial consonant \#-

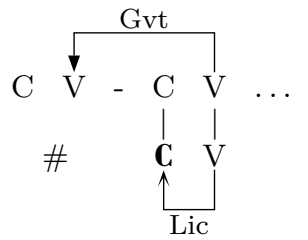

(b) post-coda consonant C.

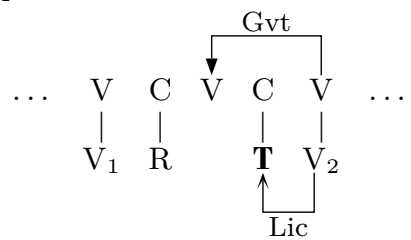

Regarding government, the two situations at hand are instances of (10ci): the government of the contentful nucleus is called to apply to the preceding empty nucleus.

The symmetric case occurs when the empty complement nucleus of a lexically long vowel calls for licensing from the nucleus to its right. This configuration is shown under (12a) below.

(12) Intervocalic licensing

(a) long vowels

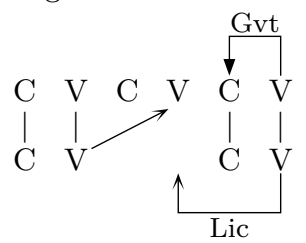

(b) intervocalic consonants

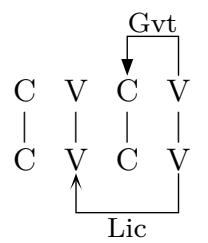

(12b) shows the situation of a simple intervocalic consonant. The comparison with the long vowel under (12a) demonstrates that unlike in the original system, intervocalic consonants after long and short vowels experience the same conditions: they are governed (and unlicensed). Recall from section 3.4 (figure (6b)) that in the original system, (12a) was the configuration that placed the intervocalic consonant in the unwarranted nightmare position.

The configuration has not changed (the consonant is governed and unlicensed as before), but the interpretation thereof is not the same anymore. That is, being governed (but unlicensed) as under (12b) are now the conditions that are experienced by regular intervocalic consonants because of (7): no constituent can be simultaneously governed and licensed. Since for that reason the source nucleus cannot license its own onset, it 
must exhaust its licensing potential by licensing the preceding nucleus (see (10a)).

\subsubsection{Closed vs. open syllables}

In the new system, contentful nuclei that are preceded by another contentful nucleus cannot license their own onset anymore. A welcome byproduct of this situation is a distinction between vowels in open and closed syllables that could not be expressed before.

(13) Definition of open vs. closed syllables

(a) Vowels in open syllables are licensed.

(b) Vowels in closed syllables are unlicensed.

That this is indeed what the new system produces may be seen when comparing the situation of (12) (where long and short vowels in open syllables are depicted) with the configuration of (11b) that shows a vowel in an internal closed syllable: $V_{1}$ under $(11 b)$ is followed by a governed empty nucleus, which is thus unable to dispense either government or licensing. That is, vowels in closed syllables are unlicensed by definition because they are followed by a laterally disabled empty nucleus.

The definition of open vs. closed syllables that was proposed in Scheer $(2004 a, \S 163)$ is less precise and also less adequate: a vowel was supposed to sit in an open syllable iff it was subject to either government or licensing. According to the new definition, vowels in open syllables can only be licensed. This makes sense: licensing enhances the segmental content of its target. Hence vocalic inventories in open syllables are expected to express the full range of melodic possibilities, while only a curtailed inventory should occur in closed syllables, which lack support from licensing. This is precisely the pattern that is pervasively observed across languages (e.g., Harris 1997). ${ }^{7}$

7 The impact (or rather: the non-impact) of the revised system of lateral relations on the representation and the behaviour of branching onsets cannot be discussed in the frame of this article. The identity of branching onsets that is presented in Scheer (1998a) (also Scheer 2004a, §14) is modified in Scheer (2000) in order to make the structure comply with locality requirements (see Brun-Trigaud-Scheer 2010). The new system of lateral relations is entirely transparent to the status of branching onsets in their local guise.

Acta Linguistica Hungarica 57, 2010 


\section{The parameterisation of FEN with non-equal righted government and licensing}

\subsection{Desiderata and relevant structures to be tested}

Table (14) below recalls the four logically possible configurations that FEN can endorse when government and licensing are independently parameterised.

(14) Independent government and licensing: logically possible parametric values of FEN

\begin{tabular}{lcc}
\hline & FEN can govern & FEN can license \\
\cline { 2 - 3 } (a) & yes & yes \\
(b) & no & no \\
(c) & yes & no \\
(d) & no & yes \\
\hline
\end{tabular}

We know that only (14a) and (14b) make sense empirically. This is why it was concluded that the lateral actorship of FEN is parameterised as a whole: either FEN are able to dispense both lateral forces, or neither.

Also recall the reason why (14c) and (14d) are unwarranted: the former produces word-final consonants in (super-weak) nightmare position, while the latter makes the outlandish prediction that there are languages where word-final consonants stand in Strong Position.

The two sections below show how things sort out when the revised version of the Coda Mirror is applied: word-final consonants should not be able to occur in either the nightmare or the strong position anymore. Also, unlike in the old system and like in the new system in word-internal position (section 4.4.1), word-final consonants should experience the same conditions after long and short vowels.

\subsection{Languages where FEN are laterally enabled (i.e., can govern and license)}

The word-final situation in languages where FEN are sound lateral actors is shown under (15) below.

Under (15a), vowels in final closed syllables may be long because the FEN is able to license their complement nucleus. Since the FEN can also 
(15) Extrasyllabicity in [+Gvt, +Lic] languages

(a) /VVC\#/ comes out long, $\mathrm{C \#}$ after long vowels is in intervocalic position

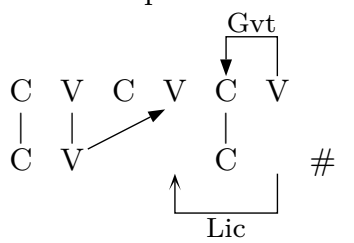

(b) $\mathrm{C} \#$ after short vowels is in intervocalic position

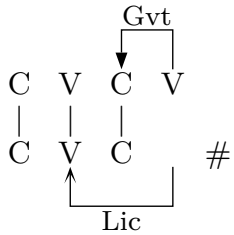

govern, the final consonant following the long vowel is governed, which means that it experiences intervocalic conditions. The same holds true for word-final consonants that occur after a short vowel as under (15b): they will be governed by the FEN; since they cannot be simultaneously licensed, the preceding vowel benefits from support, which means that it stands in an open syllable.

In sum, thus, all word-final consonants are intervocalic in this type of language, and vowels followed by word-final consonants always stand in open syllables. Word-final consonants never experience different conditions according to whether they are preceded by a long or by a short vowel-exactly what we wanted to achieve.

The language at hand where FEN are sound lateral actors is the description of an extrasyllabic language: word-final consonants "do not count"; that is, they do not behave like codas, which also makes preceding vowels display open syllable behaviour.

\subsection{Languages where FEN are laterally disabled (i.e., can neither govern nor license)}

(16) below shows the right edge of words in languages where FEN cannot dispense lateral forces.

(16) Extrasyllabicity in [-Gvt, - - Lic] languages

(a) /VVC\#/ comes out short, $\mathrm{C \#}$ is in coda position

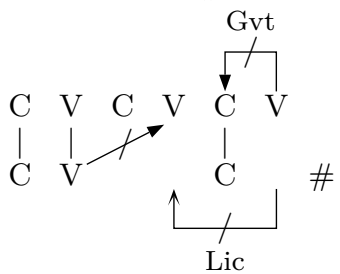

(b) $\mathrm{C} \#$ is in coda position

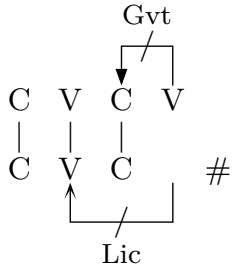

Acta Linguistica Hungarica 57, 2010 
Since FEN are laterally disabled, word-final consonants are always ungoverned (and of course unlicensed), after long as much as after short vowels. That is, they stand in coda position. Also, vowels in final closed syllables cannot be long since the nucleus of their second leg will fail to be licensed by the FEN. Finally, note that both long and short vowels experience the conditions of closed syllables: they suffer from the absence of licensing.

The language described is thus non-extrasyllabic on all counts: wordfinal consonants "count"; they therefore behave like codas and close their syllable, which means that preceding vowels experience closed syllable effects.

\section{Why there is no word-initial variation and why only $\mathrm{C}$-final words produce variation}

\subsection{Morpheme-final is phase-initial}

Let us now consider two questions: why do languages display parametric variation at the right, but not at the left edge of words? And why is the right-edge variation only encountered with consonant-final words? In other words, why are there extrasyllabic consonants, but no extrasyllabic vowels? Nothing withstands a scenario where word-final vowels are extrasyllabic (Scheer 2004a, §549): in some languages, vowel-final words could behave as if the vowel were not there; the preceding consonant would then have coda status. In other languages where final vowels are not extrasyllabic, the preceding consonant would then be regular onsets. This kind of variation is not on record.

The answer to these questions is in-built in CVCV and the way it conceives of phonological computation. Let us first make explicit the fact that the stretch of the linear string whose right edge we are talking about is the phase (or cycle in more traditional phonological terminology, or the domain in GP-coined terms). Cyclic (or inside-out) derivation, a cornerstone of generative grammar, supposes that syntactic structure is interpreted piecemeal: rather than in one single go, phonological computation applies to strings of growing size from the most to the least embedded item. In modern phase theory, these are called phases (Uriagereka 1999; Chomsky 2000 and following).

Let us now look at what happens when a phase-defined string arrives in phonology. On the account of $\mathrm{CVCV}$, two properties of phonological 
interpretation are hard-wired: all strings end in a nucleus, and they are parsed from right to left, hence starting with the last nucleus. Regressive interpretation follows from the fact that all lateral relations (and almost all phonological processes) are head-final (Scheer 1998b; 2004a, §218). That is, phonological computation in CVCV consists of the application of government and licensing to a string that is made of onsets, nuclei and (eventually) associated melodic material. Given that lateral relations are head-final, the lateral status of constituents (i.e., whether they are governed and/or licensed, and in turn whether they can govern and/or license) is always determined by the lateral status of a constituent to their right. Therefore the computation of constituent $n$ supposes that the phonological status of constituent $n+1$ is already determined. Hence phonological computation parses the string from right to left.

FEN are thus the last item in the string (from the point of view of Western spelling), but they are the first item to be processed by phonological computation: FEN are phase-initial.

\subsection{There are no extrasyllabic vowels because contentful nuclei come with full lateral specifications}

If a consonant-final string is in fact FEN-final, and if FEN are phase-initial, it follows that variation is only encountered at the right edge of consonant-final words. The difference between an empty and a contentful nucleus is that the latter inherits full phonological abilities from its melodic content: contentful nuclei are always good governors and good licensors. Empty nuclei, on the other hand, have no phonological properties per se: their governing and licensing abilities depend on whether they are subjected to government or not.

In case the first item that is hit by phonological computation is a(n) (final) empty nucleus, its phonological properties must somehow be defined. Everywhere else in the string, the lateral properties of constituents are defined by constituents to their right. That is, phonological computation cannot begin unless the phonological properties of its first domino are defined. Since the phase-initial nucleus itself does not bear any in case it is empty, a surrogate mechanism must provide the information that is necessary in order to initiate the computation. This is done by a parameter setting. In case the last nucleus is contentful, no such crutch needs to be recurred to: contentful nuclei come with full lateral equipment. 
This scenario also explains why there is no equivalent variation at the left edge of words (or phases): the left edge is computation-final, which means that nuclei never lack lateral specifications.

\section{Conclusion}

In the system of Scheer (2004a), government and licensing were independent actors, both regarding the Coda Mirror and the parameterisation of FEN. In this article, their equal-rightedness was identified as a factor of overgeneration. Against this backdrop and following Cyran (2006), a hierarchical relationship between government and licensing was introduced: in case a constituent could be subject to both forces, it will only be governed. This move modifies the engine of the Coda Mirror regarding intervocalic consonants, which are now only governed (while they were both governed and licensed before). The parametric system of FEN was also revised according to the new rule.

The new system provides a comprehensive definition of the difference between open and closed syllables: Nuclei in open syllables are always licensed, which explains why vowels in this position show the maximal vocalic inventory. They are unlicensed (i.e., unsupported) in closed syllables and therefore typically host inventories whose melodic distribution is curtailed.

A last virtue of the Coda Mirror v2 to be mentioned is that it does away with the schizophrenia of intervocalic consonants. These were both governed and licensed before, and it was unclear how they could obey both antagonistic forces at the same time, or why they do not cancel each other out. In the amended system, schizophrenic consonants do not occur anymore since no constituent can be simultaneously governed and licensed.

\section{References}

Balogné Bérces, Katalin 2001. 'Ambisyllabicity' across word boundaries: A Strict CV Phonology approach. In: DOXIMP 6. Selected papers, 1-8. Elméleti Nyelvészet Program (ELTE), MTA Nyelvtudományi Intézet, Budapest. (Also appeared in: SOAS Working Papers in Linguistics and Phonetics 11:47-55.)

Balogné Bérces, Katalin 2005. Strict CV phonology and the English cross-word puzzle. Doctoral dissertation, Eötvös Loránd University, Budapest. 
Brun-Trigaud, Guylaine-Tobias Scheer 2010. Lenition in branching onsets in French and in ALF dialects. In: Petr Karlík (ed.): Development of language through the lens of formal linguistics, 15-28. Lincom, Munich.

Carvalho, Joaquim Brandão de-Tobias Scheer-Philippe Ségéral (eds) 2008. Lenition and fortition. Mouton de Gruyter, Berlin \& New York.

Chomsky, Noam 2000. Minimalist inquiries: The framework. In: Roger Martin-David Michaels - Juan Uriagereka (eds): Step by step: Essays on minimalist syntax in honor of Howard Lasnik, 89-155. MIT Press, Cambridge MA.

Csides, Csaba 2000. Government and licensing: A CV analysis of consonant lenition. In: SOAS Working Papers in Linguistics and Phonetics 10:41-80.

Csides, Csaba 2007. A strict CV approach to consonant lenition: Bidirectional government in English phonology. In: Language Sciences 29:177-202.

Cyran, Eugeniusz 2003. Complexity scales and licensing strength in phonology. Wydawnictwo Kul, Lublin.

Cyran, Eugeniusz 2006. Book review: A lateral theory of phonology, by Tobias Scheer. In: The Linguistic Review $23: 505-42$.

Cyran, Eugeniusz 2008. Consonant clusters in strong and weak positions. In: de Carvalho et al. (2008, 447-81).

Harris, John 1997. Licensing inheritance: An integrated theory of neutralisation. In: Phonology $14: 315-70$.

Kaye, Jonathan D. 1995. Derivations and interfaces. In: Jacques Durand-Francis Katamba (eds): Frontiers of phonology: Atoms, structures, derivations, 289-332. Longman, Harlow.

Kijak, Artur 2005. Polish and English complex consonantal onsets: A contrastive analysis within the Government Phonology framework. Doctoral dissertation, University of Katowice.

Lowenstamm, Jean 1996. CV as the only syllable type. In: Jacques Durand-Bernard Laks (eds): Current trends in phonology. Models and methods, 419-41. European Studies Research Institute, University of Salford Publications, Salford.

Lowenstamm, Jean 1999. The beginning of the word. In: John Rennison - Klaus Kühnhammer (eds): Phonologica 1996. Syllables!?, 153-66. Holland Academic Graphics, The Hague.

Marotta, Giovanna 2008. Lenition in Tuscan Italian (Gorgia Toscana). In: de Carvalho et al. $(2008,235-71)$.

Passino, Diana 2008. Aspects of consonantal lengthening in Italian. Unipress, Padova.

Rowicka, Grażyna 1999. On ghost vowels: A Strict CV approach. Holland Academic Graphics, The Hague.

Scheer, Tobias 1998a. A theory of consonantal interaction. In: Folia Linguistica (Acta Societatis Linguistica Eurpaeae) $32: 201-37$

Scheer, Tobias 1998b. A unified model of Proper Government. In: The Linguistic Review 15:41-67.

Scheer, Tobias 1998c. Governing domains are head-final. In: Eugeniusz Cyran (ed.): Structure and interpretation. Studies in phonology (PASE Studies \& Monographs 4), 261-85. Wydawnictwo Folium, Lublin.

Acta Linguistica Hungarica 57, 2010 
Scheer, Tobias 2000. De la localité, de la morphologie et de la phonologie en phonologie. Habilitation thesis, Université de Nice.

Scheer, Tobias 2004a. A lateral theory of phonology. Vol 1: What is CVCV, and why should it be? Mouton de Gruyter, Berlin \& New York.

Scheer, Tobias 2004b. How minimal is phonological change? In: Folia Linguistica Historica $25: 69-114$.

Scheer, Tobias forthcoming. How morpho-syntax talks to phonology. A survey of extraphonological information in phonology since Trubetzkoy's Grenzsignale. Mouton de Gruyter, Berlin \& New York.

Ségéral, Philippe-Tobias Scheer 1999. The Coda Mirror. Ms. Université de Paris 7 and Université de Nice. (Slightly less evolved English version of Segeral - Scheer 2001a.)

Ségéral, Philippe-Tobias Scheer 2001a. La Coda-Miroir. In: Bulletin de la Société de Linguistique de Paris $96: 107-52$.

Ségéral, Philippe - Tobias Scheer 2001b. Les séquences consonne + yod en gallo-roman. In: Recherches Linguistiques de Vincennes $30: 87-120$.

Ségéral, Philippe-Tobias Scheer 2005. What lenition and fortition tells us about Gallo-Romance Muta cum Liquida. In: Twan Geerts-Ivo van Ginneken-Haike Jacobs (eds): Romance languages and linguistic theory, 235-67. John Benjamins, Amsterdam \& Philadelphia.

Ségéral, Philippe-Tobias Scheer 2008a. Positional factors in lenition and fortition. In: de Carvalho et al. (2008, 131-72).

Ségéral, Philippe-Tobias Scheer 2008b. The Coda Mirror, stress and positional parameters. In: de Carvalho et al. (2008, 483-518).

Seigneur-Froli, Delphine 2003. Diachronic consonant lenition and exotic word-initial clusters in Greek: A unified account. In: Melita Stavrou-Sifaki-Asimakis Fliatouras (eds): Studies in Greek Linguistics 23. Proceedings of the 23rd Annual Meeting of the Department of linguistics of AUTH, 345-57. University of Thessaloniki, Thessaloniki.

Seigneur-Froli, Delphine 2006. Le statut phonologique du début de mot grec. Lénitions consonantiques et libertés phonotactiques initiales dans la diachronie de la langue commune et dans le dialecte de Lesbos. Doctoral dissertation, University of Nice.

Szigetvári, Péter 1999. VC Phonology: A theory of consonant lenition and phonotactics. Doctoral dissertation, Eötvös Loránd University/MTA, Budapest.

Szigetvári, Péter 2001. Dismantling syllable structure. In: Acta Linguistica Hungarica $48: 155-81$.

Szigetvári, Péter 2008. Two directions for lenition. In: de Carvalho et al. (2008, 561-92).

Uriagereka, Juan 1999. Multiple spell-out. In: Samuel Epstein-Norbert Hornstein (eds): Working minimalism, 251-82. MIT Press, Cambridge MA.

Ziková, Markéta 2008. Alternace e-nula v současné češtině. Autosegmentální laterální analýza. Doctoral dissertation, Masarykova univerzita v Brně. 